\title{
THE SAFE HOUSE
}

\author{
Lakan Daza Umali \\ University of the Philippines Mindanao \\ Idumali3@up.edu.ph
}

\begin{abstract}
About the Author
Lakan Daza Umali is a writer currently based in Davao City, where he teaches at the University of the Philippines Mindanao.
\end{abstract}


There were three of them waiting for Bobbie to enter the front door: Selene, curly hair wild around her head and unlit cigarette in her mouth, sitting by the circular plastic table that functioned as their collective's dining area; Carlos, splayed on the thin sleeping mat and lazily strumming his guitar, an empty beer bottle-the only decadence he allowed himself-resting at his feet; and Connie, the colegiala whose convent-bred English allowed them to expand their publication's reach to the middle class, sitting by the wall opposite Carlos and rereading Amado Guerrero's Philippine Society and Revolution, attempting to internalize the difference between a semi-feudal and semi-capitalist society. A clock hung above the front door. Like a warning, it said that it was already six-thirty in the evening. In an hour, it would be seven-thirty. And in two hours, thought Connie, they might be dead.

She could barely read the words in her book; they were a haze of black marks swimming on the page. Her eyes kept straying to the clock, its second hand moving perilously forward, each tick bouncing off the safe house's bare, rain-stained walls. Usually at this hour, they would be preparing dinner. But all they had in the dingy, rust-infected refrigerator were a few pinches of salt, a plastic bag of rice, and half an onion. On the kitchen counter, there was a half-filled thermos of lukewarm water, along with a few teabags, and a plastic jar of instant coffee. Bobbie was supposed to have returned from the market half an hour ago to replenish their supplies with new rations, some still fresh from liberated zones, but the sun had already set and he was still nowhere in sight.

“Is it okay if I light this?” Selene asked, pointing to the cigarette in her mouth.

Carlos stopped strumming. He gestured at the piles of Sigwa $n g$ Bayan laying all around the safe house, tiny towers of paper still fresh from the clunky gray mimeograph. "Do you really think that's a good idea in this firetrap?" he asked.

Connie heard Selene mutter a soft "Christ" under her breath. She got up and charged out of the back door, into the garden behind the house. Connie liked calling it a garden. It was a small square of land with a few patches of grass, enclosed by low, concrete walls which separated their lot from the others in the compound, and contained a few pots of wilting, purplish Ti plants. The safe house itself stood on a plot of even dustier earth situated at the border of two barangays. There were only a few dozen residents in the area, mostly factory workers who couldn't afford to live anywhere else. The barangay was almost deserted. The roar and sizzle of nearby factories drove away most potential homeowners, which was perfect for the collective, who could print their materials in relative peace.

Connie missed being surrounded by the natural world. She often found herself longing for the guava trees and seaside of her family's estate in the south. Around 
their mansion were rice fields high enough to reach her waist, a green sea waiting to protect her from all the evil beings in the country beyond. Whenever those pastoral fantasies returned, she had to remind herself that such beauty was built on the sweat and blood of her father's retinue of workers.

Now, everything around her was drab: the faded brown of the safe house interior, gray copies of Sigwa ng Bayan, empty black bags scattered on the floor, ready for quick escapes. Soon, she would be surrounded by the endless green of the countryside, its proud red banners fluttering in the wind, nights illuminated by the bright orange of campfires. The prospect made her lightheaded whenever she thought of it.

Connie kept the book firmly in front of her face. She was worried she would erupt in a nervous stream of giggles, which would lead to a prolonged wail of crying that would only reaffirm Carlos and Selene's suspicions of her: that she wasn't ready for the UG, that she still had to unlearn much of her bourgeoisie comforts. They had mentioned this during one of their group assessments. They couldn't keep it secret from her, as backbiting and gossiping were diseases of liberalism, so they had to tell their grievances straight to her face. The book kept her from breaking. Even though the words were a blur, she could still pick out a few key phrases: feudalism, imperialism, the landlord class, the national democratic revolution. They steadied her. They reminded her that she was trying to fight for a cause greater than herself. Once, she remarked to Bobbie that revolution seemed like such an abstract concept. He told her to wait until they reached the countryside, where revolution would become a concrete reality she'd wake up to every day, one they would soon bring to the entire nation. The real countryside, he added. By that, he meant the countryside beyond the army of maids and drivers of her family's household, and the manicured drawing rooms of her childhood.

Carlos began strumming a different song. With the opening few notes, she recognized it as an instrumental version of "The Internationale."

"I think Selene's right," Connie said. "We should leave. Go to back to HQ. If Bobbie arrives, he'll know to look for us there."

Carlos didn't even stop playing. His eyes were fixed on the neck of his guitar. "Don't worry, comrade," he said. "Bobbie will arrive soon. I'm sure of it."

“How do you do it?" Connie asked.

"Do what?" 
"Be so calm."

"My brother's organizing workers at a garment factory nearby," he said. "My parents are in a liberated zone somewhere in Cordillera. Growing up, if I had been worrying every minute whenever someone hadn't come home on time, what would I have accomplished? Besides, they usually come back." He plucked a note, piercingly high, like an alley cat's screech.

Selene returned from the backyard. She sat at the table and tapped her fingers on its plastic surface. Her head turned towards the pale, bloodless face of the clock, which now read a quarter until seven. Carlos put down his guitar, his stare alternating between the two women.

"We should leave," Selene said. "He's more than an hour late."

“Just wait," Carlos replied. "It's Bobbie. You know how careful he is. He wouldn't let himself get caught on a trip to the market, of all things."

"You overestimate him," she replied.

"Maybe you underestimate him," he replied.

Selene ignored his remark. "A few nights ago I heard the neighbors talking about a break-in at one of the houses next door," she said. "And this afternoon I saw an ice cream vendor lingering outside."

“That's normal."

"An ice cream vendor?" Selene repeated. "In the middle of a no man's land in Valenzuela?"

"Workers have kids. And kids like ice cream."

"How can you be so cool about this?" she protested. "Do you think that getting caught is some game? They killed a kid for questioning the First Daughter's qualifications for youth council. Imagine what they'll do to us."

Carlos sat up and straightened his back. He fixed his stare onto Selene. "If we leave now and Bobbie arrives five minutes later, he'll have no car, no safe house to stay for the night," he said. "We wait two hours. If he hasn't returned by nine, we pack up and drive to the HQ in Karuhatan." 
Selene crossed her arms and returned his glare. She bit her lower lip and retrieved a copy of Sigwa ng Bayan, plopping herself on the mat next to Connie, thumbing through the publication's thin pages, filling the safe house with the smell of fresh ink. Outside, Connie heard a dog barking, and a gruff voice ordering him to shut it. The long drawl of a motorcycle's engine interrupted the quiet night. It stopped at a nearby house.

The collective heard three knocks on the front door. Selene shot up and was about to leap forward to answer when Carlos gestured for her to stay put. He looked at Connie and pointed at the wooden chest where they kept their clothes and other valuables. She crept to it. She opened its lid and fumbled around the clothes until her hands felt the steel grip of the pistol at the bottom.

"Who is it?" Carlos asked.

"It's Marvin," a voice replied. Carlos let out a long breath and opened the door.

When Marvin entered, he was accompanied by a man clinging to his shoulder. The man had brown, shiny skin, bushy eyebrows, and a balding forehead. He wore a white T-shirt stained with black streaks and ripped in several areas, and blue jeans in a similar, sorry condition. Connie saw a long length of ripped fabric and a gash of red running along his right leg, just above the knee. She and Selene helped Marvin lay him down on Bobbie's sleeping mat. The man let out a ragged moan, and his hand groped for the wound on his leg but Marvin kept him from touching it.

"Shh, Ka Noli, it's okay," he replied. "The wound isn't that deep. We can clean it and then it'll be okay."

"Who is he?" Selene asked. She and Connie went to the wooden chest. They pulled out handfuls of clothes until they saw the first aid kit. Selene rushed to the kitchen for a bowl of clean water.

"He teaches at the state university. He's also a labor organizer," Marvin replied. "Ka Noli and I were in the picket line at Bluefields, the garment factory, when someone threw a pillbox at the crowd."

Selene returned from the kitchen. Connie asked Ka Noli to remove his pants. The man looked down at his legs, and she thought he appeared hesitant at undressing in front of two young women. She told him that the wound might get infected if not cleaned properly, and that he might lose his leg. Ka Noli stripped off his pants, revealing a pair of wiry, hairy limbs. 
Marvin and Carlos were talking in one corner of the room while they treated Ka Noli's wound. With a pair of tweezers, Connie picked out the pieces of dirt and glass that had clung to the dried blood, while Selene used a washcloth to clean the area around the gash and applied a cotton ball soaked in iodine. The man winced and tried to pull away.

"I'm sorry," Selene said, retrieving a roll of gauze. "This will be over quickly."

Connie had seen deeper wounds. She still winced whenever she remembered the shard of glass that had embedded itself in Bobbie's left foot when they had fled from the dispersal at the US Embassy. It had left him a wormish scar and a deep distaste for slippers, especially those with thin soles. But this man had lost much blood, judging by how much red had seeped into his blue jeans, now a heap on the floor. Connie hummed a lullaby to steady her hand as she wrapped the gauze around his leg and taped the dressing in place.

"Ka Noli," Connie said, trying to summon as much charm as possible. "You look so familiar. Did you ever teach journalism at the state university?"

"Yes, I did," he replied. His face seemed to relax. "Ah, that's why you seemed so familiar, hija. You were in my Intro to Journalism class. I remembered you could barely speak a sentence in Filipino."

"Look at me now," she replied.

Marvin and Carlos finished their discussion and squatted beside the group. Connie noticed a change in Carlos's expression. It had darkened, his eyes gazing closely at the nothing of the blank wall behind them, his lips shut tightly together. Selene had also noticed the shift and tried to place a hand on his shoulder. $\mathrm{He}$ shrugged her away.

“Thank you, but we have to go," Marvin said as he and Carlos stood up.

“Wait, where are you two going?" Selene asked, hurrying to follow them.

"My brother got caught by the riot police at the picket line. Some comrades managed to rescue him, but he got really hurt," he replied. "Marvin said he's recovering at another safe house along Prudencia Street."

Prudencia was on the other side of the city, Connie thought. It might as well have been an entire island away. Ka Noli attempted to get up. He made it to a halfcrouch before tumbling down in pain. 
"He's too weak to travel," Selene told Marvin. "He has to rest here tonight."

Marvin nodded, and Ka Noli bowed his head in resignation.

"But what about Bobbie?" she asked.

"Connie knows how to drive," he said, looking at the clock. It was half past seven. "If he doesn't arrive by nine, go to the safe house in Karuhatan. I'll meet you there tomorrow."

Selene crossed her arms, and let out a sigh that reminded Connie of her own mother.

"Please, it's my brother," he added. "Just tell Bobbie I went to No. 17 Prudencia Street. He'll understand." And they could only watch him drift out of the front door, into the black and alien night beyond the safe house. A motorcycle hummed and came to life, and it roared down the street outside until it vanished in the distance.

“Do you happen to have any coffee?" the professor asked.

"Of course, he's a teacher from the state university, of course the first thing he'll ask for is coffee," Selene muttered to herself as she made her way to the kitchen. Ka Noli heard her and laughed. He tried to stand once again, but Connie made him stay down.

Ka Noli took a copy of Sigwa ng Bayan from a nearby pile. He peered at the cover, a cartoon eagle playing with puppets of the President and First Lady, and then browsed through its contents.

"Very good," he told Connie. "I can see now why I didn't fail you."

"We're doing production," she said. "I thought we had shitty printing facilities in the college, but they're heaven compared to the equipment we have here." She gestured at the ancient mimeograph sitting on the table, threatening to overpower it with its weight.

"You young ones don't know how lucky you are," he said. "After the First Quarter Storm, we had to use silkscreens and squeegee each copy by hand. We had to dry them on clotheslines like they were laundry. Sometimes the wind would even carry them away, and we had to chase them down the street, or else they might land on a policeman's feet and he'd see the cartoon we made of Macoy serenading Dovie Beams." 
"I think I was in Grade 4 then," Connie teased him, smiling.

"Don't make me feel older than I already am," he replied.

Selene returned with a cup of tepid coffee.

"We're sorry this is the most we can offer," she said. "Bobbie was supposed to have returned with supplies."

"Who is Bobbie?" the professor asked.

“Our collective leader," Connie replied.

"And what time was he supposed to have arrived?"

"He went to the market in Karuhatan," Selene said. She looked at the clock. It was a quarter past eight. "He said he would be back by six-thirty."

"You should get your things ready, he said, taking a sip of coffee. "Do either of you know how to drive?"

Connie nodded.

"Good."

Selene gathered her pack of Marlboros and lighter and wandered out the back door. Connie decided to follow her. She found her standing in the middle of the garden, her head craned up at the sky, her hand tapping cigarette ash to the ground below her. Selene offered Connie a cigarette. She declined.

"You must understand," Selene said. "If Carlos can have his bottles of San Miguel, and if you can have your hourlong baths, you must forgive me this one form of decadence."

"I don't take long baths," she replied.

"Honey, at one point we were all close to standing on the table and talking about the right of the masses to clean and adequate water," Selene said.

Connie laughed. It felt good to laugh. For a moment, she pretended she and Selene were just two co-eds, sneaking out of the dorm for a late-night smoke, trading gossip about the dark-eyed boy in English class. She sometimes longed for 
the trifles of ordinary life, the moments when the world didn't seem balanced at knifepoint, or when nights didn't mean escaping from house to house, nameless street to nameless street, hunched in a beat-up Beetle containing the entirety of her life and that of her collective's. She often banished such thoughts as soon as they came, but she sometimes let them linger. They let her glimpse into alternate worlds, alternate futures, much like the future promised by Bobbie and the revolution. Alternate futures fueled her days. Futures without pillboxes thrown at crowds, or landlords, or martial law.

Connie thought the wind was whistling in her ears when she realized it was Selene singing. She recognized the first few bars. It was a song by a local folk band, about waiting for a lover's early arrival at twilight, and about love being a free bird in an infinite sky. Selene's voice grew stronger as it neared the chorus, until she noticed Connie looking at her and abruptly stopped.

"Don't stop," she said. "You have a lovely voice."

"Thank you," she said. "It was my sister's favorite song. Before I went full-time, I'd come back home every month to visit her, and we'd sing it every night. Until she got arrested."

"Breaking curfew," Selene added, dropping her spent cigarette to the ground and crushing it with her foot. "Can you believe it? Getting arrested for a night out with friends? Fucking fascists."

Three knocks rang in the little house, and they both rushed inside to answer. Connie waited beside the chest, her hand ready to reach for the pistol, while Selene stopped a few feet away from the door.

"Who is it?" Selene called out.

"It's Bobbie," a voice answered. Selene shot forward to unlatch the bolt, opened the door, and embraced him as soon as he set foot in the safe house.

"Fuck you," she said. "Why are you so late?"

"We have to go. Now," he said, barreling through the safe house. He moved quickly, stuffing propaganda materials, shirts, and rolls of ink into the empty bags scattered on the floor.

"Who is he?" he asked, gesturing to Ka Noli. "And where's Carlos?" 
"Ka Noli. Journalism prof and labor organizer. Got hurt in a dispersal a while ago. Marvin took him here to get help," Selene replied. "Carlos went with Marvin to a safe house in Prudencia to look after his brother."

"Dispersal? So it is true. They're cracking down, which means we need to hurry," he said.

“Cracking down on what?” Connie asked.

"The HQ in Karuhatan. I decided to stop by there after going to the market," he said. "Its gate was open, its windows smashed, its front door broken. We've been compromised. We have to assume they know the entire network of safe houses in Valenzuela."

They had no time to mourn. Selene wordlessly went to pack up their collective's things, careful not to leave behind a stencil or ink cartridge. Connie helped Bobbie carry the bulky mimeograph to the brown Beetle parked along the curb. Stacks of papers were placed in boxes. Printing materials were stowed away while brochures, pamphlets, and other contraband literature like little red books were stuffed in duffel bags. They packed up the rest of their belongings: a few pieces of clothing, the sleeping mats, the first aid kit, Carlos's guitar, a deck of cards. By the time they finished, the little living room was free of everything except for the wooden chest, the rickety table, the clock, and Ka Noli's soiled pants; he wore a pair of Carlos' old PE shorts. Connie looked at the bare room and realized how small it was. She had trouble imagining how four young adults had managed to fit in a space only a little bigger than a child's playpen.

They squeezed into the tiny brown Beetle. Ka Noli sat in the passenger seat to give his injured leg space to breathe, while Connie and Selene crammed themselves into the back, the mimeograph squashed between them, its metal body poking their ribs. Despite the discomfort, Connie's limbs grew heavy, the days of seemingly endless editorial work finally catching up, and she soon fell asleep.

A voice woke her.

“What number was the safe house again?" Bobbie asked.

“Carlos said it was on No. 17 Prudencia Street," Selene replied. 
The car cruised along a deserted road flanked by bungalows colored a sickly yellow by the streetlamps. The houses were all dark and devoid of any bright color, save for the occasional tree on the front lawn. Bobbie drove slowly enough for them to read the numbers on the front of every house.

"What number are we passing by?"

Selene rolled down her window and craned her neck outside.

"Four," she said. "Even numbers seem to be on my side of the street. Connie, oh good, you're awake. Tell us if you see a No. 17 on your side."

The street was quiet except for the soft muffle of the Beetle's engine and Ka Noli's snoring in the front seat. Connie stuck her head out of the window to peer at the house numbers outside.

"Five, seven, nine," she counted, as the car inched its way forward.

When they reached No. 17, Bobbie was about to park the car when Connie noticed that it was another empty house. The gate swung back and forth as if it were waiting to be shut. The front window was smashed in. The front door was wide open, showing the black absence within.

"Don't stop," Connie whispered in Bobbie's ear.

"I know," he said, speeding up.

Connie lay back against her seat. She looked at Selene, hoping for a gentle word, or for her to take Connie into her arms and tell her that it was going to be okay. Instead, Selene's mouth hung open. Her eyes were cast downward, and her face glistened yellow in the sickly glow of the streetlamps.

Connie felt the car lurch forward, gaining traction as they hurtled past the other dark-mouthed houses of the barangay. They needed to get out of this city, where every lingering second might spell capture, or worse. She didn't know where they were headed. As the car sped trackless into the night, she took a deep breath and let the heaviness descend to her chest. In the dim interior of the car, she realized this was one of the few moments that allowed her space to grieve. She needed to make the most of it. 